\title{
The Role of Government Regulations in Enhancing Corporate Social Responsibility Disclosure and Firm Value
}

\author{
Faisal FAISAL ${ }^{1}$, Lilis Suryani SITUMORANG ${ }^{2}$, Tarmizi ACHMAD ${ }^{3}$, Andri PRASTIWI ${ }^{4}$ \\ Received: May 23, 2020 Revised: May 31, 2020 Accepted: July 03, 2020
}

\begin{abstract}
This study investigates, first, whether the extent of corporate social and environmental responsibility disclosure (CSERD) differs between 2010 and 2014; second, whether government regulation affects the extent of CSERD; and, third, whether the CSERD is valued by investors. Content analysis method was used to extract 466 companies' annual reports to measure the extent of social and environmental responsibility disclosure based on the Global Reporting Initiative (GRI) checklist. Independent sample t-test and multivariate regression analysis were also conducted to test the differences of the extent of CSERD as well as determinants and consequence of CSERD. Our results show that the extent of CSERD in 2014 is 21.60 percent higher than in 2010 (13.39 percent). Government regulation has a significant effect on the extent of CSERD. This study also finds that market values positively CSER information disclosed by company. Given that government regulation has a positive impact, however, the findings of this study suggests that the extent of CSERD is still low. To enhance CSERD, government should continuously encourage companies to abide by the regulations as mandated. This study provides a more comprehensive insights of CSRED practices from an emerging country and the effect of government regulation in enhancing CSERD.
\end{abstract}

Keywords: CSR, Disclosure, Sustainability, Government Regulation, Firm Value

JEL Classification Code: M14, M40, M41, M48

\section{Introduction}

Corporate social and environmental responsibility disclosure (CSERD) is a trend that developed in the last two decades. Companies have demonstrated increasing interest

${ }^{1}$ First Author and Corresponding Author. Professor, Accounting Department, Faculty of Economics and Business, Universitas Diponegoro, Semarang, Indonesia [Postal Address: Jalan Prof. Sudarto, Tembalang, Semarang, 50275, Indonesia]

Email: fe_faisal@yahoo.co.id

${ }^{2}$ Accounting Department, Faculty of Economics and Business, Universitas Diponegoro, Semarang, Indonesia.

Email: lilissuryani289@yahoo.com

${ }^{3}$ Accounting Department, Faculty of Economics and Business, Universitas Diponegoro, Semarang, Indonesia.

Email: t_achmad@yahoo.com.au

${ }^{4}$ Accounting Department, Faculty of Economics and Business, Universitas Diponegoro, Semarang, Indonesia.

Email: andriprastiwi@lecturer.undip.ac.id

(C) Copyright: The Author(s)

This is an Open Access article distributed under the terms of the Creative Commons Attribution Non-Commercial License (http://Creativecommons.org/licenses/by-nc/4.0/) which permits unrestricted noncommercial use, distribution, and reproduction in any medium, provided the original work is properly cited. in communicating their CSER information in their annual, stand-alone and integrated reports, and websites (Faisal et al., 2012; Garcia-Sanchez et al., 2016; Kuzey \& Uyar, 2017). The increase in the number of CSERD also followed the increasing interest of researcher to investigate determinants and the motivation of companies in disclosing CSER information (Ali et al., 2017; Haji, 2013). Prior studies on CSERD argued that firm characteristics such as company size, industry type, capital structure, profitability, media visibility, ownership structure, and corporate governance predominantly appear to be as determinants both in developed and emerging countries (Ali et al., 2017; Dienes et al., 2016; Hahn \& Kühnen, 2013). Although prior studies have examined factors influencing CSERD, however, little research has investigated the impact of government regulations on the extent of CSERD, especially in Indonesia (see Table 1).

The Indonesian government has issued several regulations related to CSER activities. For example, some regulations require companies that use natural resources (i.e., extractive sectors) in the company's operational practices to 
report their CSER activities. The obligation to report these activities is legislated in Company Law Number 40 (2007) and government Regulation Number 47 (2012). These laws require companies running their business activities in the field and/or related to the natural resources (i.e., agriculture, plantation, animal husbandry, fishery, forestry, mining, coal mining, crude petroleum, natural gas production, metal and mineral mining, and land/stone quarrying) to implement social and environmental responsibility (Article 74 paragraph 1). Any company that does not perform this obligation will be sanctioned in accordance with the provisions of the legislation (Article 74 paragraph 3). In line with Company Law Number 40 (2007), the government Regulation Number 47 (2012) strengthens CSER as the obligation for the company that runs its business activities in the field and/or related to natural resources (Articles 3 paragraph 2).

Previous studies suggested that there is a need for research in the field of CSER to give a greater attention of the role of institutional mechanisms such as government's role in motivating companies to disclose information CSER. Economic factors and financial performance alone are not enough to explain the behavior of the social responsibility of organizations (Marquis et al., 2007). Evidence showed that institutional pressures such as government regulations are still a key factor in motivating companies in China and Malaysia to disclose CSER information (Othman et al., 2011; Zheng et al., 2014). The existence of government regulations is relevant as it may reduce public pressures (Ali et al., 2017; Barakat et al., 2015). Therefore, the first objective of this study is to investigate whether the extent of CSRED has increased after the government regulation Number 47 (2012) was released.

In term of motivation of companies in disclosing CSER information, empirical studies showed that researcher are still debating what motives companies to disclose their CSER information (Deegan, 2002). Studies in emerging countries argue that legitimacy is the fundamental motivation for CSERD (Coetzee \& van Staden, 2011; Djajadikerta \& Trireksani, 2012; Gunawan, 2007; Kuzey \& Uyar, 2017; Ling \& Sultana, 2015; Mahadeo et al., 2011; T. L. H. Nguyen et al., 2020). However, some prior studies also argue that institutional pressures are a factor that motivates companies to react to demands for CSERD (Cahaya et al., 2012; Pedersen et al., 2013). The majority of CSERD studies conducted in emerging economies generally are limited to a narrow range of countries such as Malaysia, South Africa, China, India, South Korea, Brazil, and Turkey. Some studies have been conducted in Indonesia (see, for example, Djajadikerta \& Trireksani, 2012; Frisko, 2012; Hidayati, 2011; Mirfazli, 2008; Oeyono et al., 2011; Rusmanto \& Williams, 2015; Santoso \& Feliana, 2014; Sarumpaet et al., 2017; Siregar \& Bachtiar, 2010; Waagstein, 2010), however, these studies do not use a specific theory in explaining motivations and determinants of CSERD (Ali et al., 2017). Studies conducted by Cahaya et al. (2012) and Cahaya et al. (2015) used institutional theory as their theoretical frameworks, yet, these studies only look at CSERD practice from the limited theme, namely, labor disclosure. Gunawan (2015) suggests that there is a need to further investigate what are the motivation and factors that encourage companies in Indonesia to disclose CSER.

This study examines factors influencing CSERD from the institutional perspectives. Institutional theory states that the organization was substantially influenced by the environment in which it operates. This study adopts the institutional theory to give insights about the motivation of companies in doing CSERD. Thus, the second objective of this study is to investigate whether government regulation as a form of coercive mimetic has a positive effect on the extent of CSERD. The finding of this study provides evidence that government regulation has a positive effect in driving the Indonesian companies to communicate more their CSER.

This study also examines whether CSERD affects the value of the firm. Cho et al. (2015) suggested that the new wave of CSER theme relates to firm value and whether CSERD is valued by market participants (Qiu et al., 2016). Some studies suggested the extent to which CSERD has a positive impact on firm value. Cormier and Magnan (2015) argued that CSERD brings not just a good image for the firms, but also creates financial benefits such as a higher share prices. Other studies are also in line with Cormier and Magnan (2015)' findings that CSERD provided a positive impact on firm value (De Klerk et al., 2015; Schadewitz \& Niskala, 2010). Nevertheless, CSERD may also interfere with the firm value (negative response) if investors view that such CSER disclosure is only a symbolic action or greenwashing behavior (Fatemi et al., 2017; Wang \& Sarkis, 2017). Our findings show that CSERD is positively valued by investors. In brief, the research propositions to be addressed are as follows: (i) whether there is an increase in the extent of CSERD between 2010 and 2014, (ii) whether government regulation has a significant impact on the extent of CSRED, and (iii) whether CSER information is valued by investors.

\section{Literature Review}

Table 1 sums up several previous studies that have been conducted in Indonesia. As highlighted, Gunawan (2007) examines CSERD practices of 68 companies in 2003-2005. Her finding suggested that to create a positive image and to comply with regulations are motivations to provide CSER information. Cahaya et al. (2008) studied the effect of firm characteristics on social disclosure of 100 firms listed on Jakarta Stock Exchange (JSX) in 2004. Using the lens of stakeholder theory, they found that the larger the companies, the higher their commitment to 
Table 1: Previous Studies on CSERD in Indonesia

\begin{tabular}{|c|c|c|c|}
\hline Study & Theory & Sample & Finding \\
\hline Gunawan (2007) & $\begin{array}{l}\text { Legitimacy, } \\
\text { stakeholder }\end{array}$ & $\begin{array}{l}68 \text { firms in 2003- } \\
2005\end{array}$ & $\begin{array}{l}\text { The average of social disclosure is } 5 \text { sentences. } \\
\text { Motivation to disclose is to create positive image, to act } \\
\text { accountability, to comply with regulations. }\end{array}$ \\
\hline Cahaya et al. (2008) & Stakeholder & 100 firms in 2004 & The extent of social disclosure is $14.5 \%$. \\
\hline Mirfazli (2008) & NS & 42 firms in 2004 & $\begin{array}{l}\text { Labor themes is the most item disclosed followed by } \\
\text { customer, environmental and society themes. }\end{array}$ \\
\hline $\begin{array}{l}\text { Siregar and Bachtiar } \\
(2010)\end{array}$ & NS & 87 firms in 2003 & $\begin{array}{l}\text { The extent of social disclosure is } 13.7 \% \text {. Size has a } \\
\text { significant effect on social disclosure. }\end{array}$ \\
\hline Oeyono et al. (2011) & NS & $\begin{array}{l}50 \text { firms in 2003- } \\
2007\end{array}$ & $\begin{array}{l}\text { Only } 11 \% \text { of } 50 \text { firms disclosed all GRI indicators } \\
\text { (economic, environmental, labor practice, human rights, } \\
\text { society, product responsibility. Profitability has significant } \\
\text { effect on CSERD. }\end{array}$ \\
\hline Cahaya et al. (2012) & Institutional & 223 firms in 2007 & $\begin{array}{l}\text { The extent labor disclosure is } 17.7 \% \text {. Government } \\
\text { ownership, size, international operation have significant } \\
\text { effect on labor disclosure. }\end{array}$ \\
\hline Frisko (2012) & NS & $\begin{array}{l}141 \text { state-owned } \\
\text { enterprises (SoEs) }\end{array}$ & $\begin{array}{l}\text { Government regulations can be used by CSER as a tool } \\
\text { to encourage SoEs to empower economic development } \\
\text { also to overcome social issues. }\end{array}$ \\
\hline $\begin{array}{l}\text { Djajadikerta and } \\
\text { Trireksani (2012) }\end{array}$ & NS & 110 firms in 2008 & $\begin{array}{l}\text { The extent of CSERD is } 15 \% \text {. Community and human } \\
\text { resources are the most themes disclosed. }\end{array}$ \\
\hline $\begin{array}{l}\text { Santoso and Feliana } \\
(2014)\end{array}$ & NS & $\begin{array}{l}800 \text { firms in } 2010 \\
-2012\end{array}$ & $\begin{array}{l}\text { The extent of CSERD is } 4.5 \% \text {. Size has a positive } \\
\text { effect on CSERD. CSRED has a positive effect on firm } \\
\text { performance. }\end{array}$ \\
\hline Cahaya et al. (2015) & Institutional & $\begin{array}{l}31 \text { in } 2007 \text { and } \\
2010\end{array}$ & $\begin{array}{l}\text { The extent of labor disclosure increase from } 21.84 \% \text { in } \\
2007 \text { to } 30.52 \% \text { in } 2010 \text {. }\end{array}$ \\
\hline $\begin{array}{l}\text { Rusmanto and } \\
\text { Williams (2015) }\end{array}$ & NS & $\begin{array}{l}100 \text { firms in 2011- } \\
2012\end{array}$ & $\begin{array}{l}\text { Only } 9 \% \text { of } 100 \text { companies provide the CSER information } \\
\text { in their sustainability report. Mining is the most sector } \\
\text { report the CSER information. }\end{array}$ \\
\hline $\begin{array}{l}\text { Famiola and Adiwoso } \\
(2016)\end{array}$ & Institutional & $\begin{array}{l}6 \text { subsidiary } \\
\text { multinational firms }\end{array}$ & $\begin{array}{l}\text { Isomorphism pattern has less effect on CSER practice of } \\
\text { multinational corporations subsidiary. }\end{array}$ \\
\hline $\begin{array}{l}\text { Sarumpaet et al. } \\
(2017)\end{array}$ & NS & $\begin{array}{l}60 \text { firms between } \\
2002-2012\end{array}$ & $\begin{array}{l}\text { Environmental performance (environmental rating) has } \\
\text { significant effect on share prices. }\end{array}$ \\
\hline
\end{tabular}

disclose CSER. Later study conducted by Famiola and Adiwoso (2016) showed that internal pressures are the main driver to disclose CSER.

DiMaggio and Powell (1983) identify three types of isomorphic mechanisms whereby the environmental pressures on the institutional organization respond in the same way: coercive, normative, and mimetic isomorphism. Coercive isomorphism is forced to occur when organizations are suppressed by other governing bodies where they depend and cultural expectations in the communities in which they operate. It is very acute when the organization is depressed by political force and facing legitimacy issues. In the context of the CSER involvement and disclosure, all three types of isomorphism can be applied to portray the corporate social value system for both regulatory and normative pressures (Mehedi \& Jalaludin, 2020). Legal environment as coercive pressure can provide a positive effect on the disclosure of CSER information. Therefore, companies may use CSERD as a way to meet stakeholder demands by enhancing the credibility of information resulting in decreased information asymmetry (MartínezFerrero \& García-Sánchez, 2017). 


\subsection{Extent of CSRD}

As explained above, the purpose of this study is to identify whether the extent of CSER disclosure differs in 2014 compared with the year 2010. There are at least two reasons to assert that CSER disclosure has increased after the issuance of Government Regulation Number 47 (2012). Firstly, prior to the dissolving of Government Regulation Number 47 (2012), there is no government regulation that governs the implementation instructions of CSER. For example, Article 4 stated that CSER is implemented by the Board of Directors under the company's annual work plan after receiving approval from the Board of Commissioners or General Meeting of Shareholders (GMS). The company's annual work plan contains planned activities and budgets required for the implementation of CSER. CSER implementation is published in the company's annual report and accounts to the GMS (Article 6. Government Regulation Number 47 (2012). Secondly, with the issuance of the regulation, it is expected that the level of CSERD will increase in the company's annual report. Xu and Zeng (2016) stated that the company should provide information on CSER in the form of disclosure that allows the community to globally monitor corporate behavior and compliance with government regulations and standards established to maintain their legitimacy in the global market place.

\section{H1: The extent of CSRD in 2014 is higher than in 2010}

\subsection{Government Regulations and CSERD}

Meyer and Rowan (1977) stated that the institutional theory based upon the notion that to survive, companies must be able to adjust to norms, traditions, and social influence. According to DiMaggio and Powell (1983), organizations are formed by the existence of the institutional environment in which they operated. The influential ideas then are institutionalized, considered, and accepted as a way of organization. The process of legitimacy is often done by organization through state pressures such as regulations. In the context of CSERD, fulfillment of obligations to disclose CSER information showed a company's desire to acquire legitimacy status of environment, both external as well as internal. The existence of adjustment on external expectations or social expectations may cause organization tendency to boost a good image. Providing information about CSER in the form of disclosure will give an opportunity to the public to monitor the company's behavior and adherence to government regulations as well as standards that have been set. This action is one way to maintain their legitimacy (Xu \& Zeng, 2016). Previous studies suggest that the legitimacy of the environment affects quality of CSERD (Aerts \& Cormier, 2009). Xu and Zeng (2016) find that mining companies in
China do disclosure CSER information in their annual report as a response to CSERD' regulations.

H2. There is a positive relationship between government regulations and CSERD

\subsection{CSERD and Firm Value}

The disclosure of CSER is one of the company's efforts to provide more extensive information than is required by laws and regulations to send a positive signal that they are obedient to the regulations (Campbell, 2000; S. L. Nguyen et al., 2020; T. M. H. Nguyen et al., 2020). Some recent studies have argued that CSER information may be reflected in the value of the company. Several previous studies have shown that more companies disclose CSER information having a higher firm value (Al-Tuwaijri et al., 2004; Atan et al., 2018; Lee et al., 2016; Li et al., 2018; Velte, 2017). However, on the other hand, some studies find varied relationship for each component of CSER (Buallay, 2019; Limkriangkrai et al., 2017). Guidry and Patten (2010) reported that there was a positive market reaction three days after the release date period of CSER disclosures.

H3. There is a positive relationship between CSERD and firm value

\section{Research Method}

This study used secondary data sourced from annual report of companies listed on the Indonesia Stock Exchange (IDX) for the years 2010 and 2014. Financial data were also obtained from Bloomberg database. To measure the extent of CSERD, 79 indicators adapted from Global Reporting Initiative (GRI) were carried out using content analysis method. The version 3.0 of GRI was chosen for the period of 2010 and 2014. By using the same version, it produced a reliable comparison as the number of items used is similar. In this case, the disclosure will be assigned a value of 1 if the item is disclosed and a value of 0 if it was not disclosed (see Table 2).

Table 3 presents the sample selection. There were 422 companies listed on the Indonesia Stock Exchange (IDX) in 2010. Although Act Number 40/2007 oblige firms to report their CSER activities, however, 189 companies did not present CSER information in their annual reports. Thus, 233 companies were selected as samples in 2010 . For 2014, the sample was selected based on the number of sample in 2010 .

Table 4 presents the sample based on sector of industry classification. Based on the industry classification of public company listed on the IDX, there are nine sectors, namely, (i) agriculture, (ii) mining, (iii) basic industry and chemicals, (iv) miscellaneous industry, (v) consumer goods, 
Table 2: Variable Measurement

\begin{tabular}{|l|l|}
\hline \multicolumn{1}{|c|}{ Variables } & \multicolumn{1}{c|}{ Measurement } \\
\hline MVE & Market value of equity \\
CSERD & Take a value of 1 if the item disclosed, otherwise 0 \\
GOVREG & Take a value of 1 for the year 2014 and 0 for the year 2010 \\
FirmSize & Total assets \\
Industry type & Take a value of 1 if the firm is categorized as high profile, otherwise 0 \\
Leverage & Total assets divided by total liabilities \\
ROA & Net income divided by total assets \\
EBIT & Earnings Before IncomeTax \\
Liability & Total liabilities \\
\hline Legends: Firm size, liability, EBIT (Earnings Before IncomeTax), and Leverage are in billion rupiahs. MVE = market value of \\
equity; CSERD = corporate social and environmental responsibility disclosure; GOVREG = government regulation
\end{tabular}

Table 3: Sample Selection

\begin{tabular}{|l|c|}
\hline \multicolumn{1}{|c|}{ Criteria } & N \\
\hline Number of firms listed on the Indonesia Stock Exchange in 2010 & 422 \\
\hline Firm that do not provide CSER section/information in annual reports in 2010 & (189) \\
\hline Number of sample in 2010 & 233 \\
\hline Firms that consistently provide CSER section/information in annual reports both in 2010 and 2014 & 233 \\
\hline Final sample & 466 \\
\hline
\end{tabular}

Table 4: Sample by Industry

\begin{tabular}{|c|c|c|c|}
\hline \multirow{2}{*}{ Sector } & \multirow{2}{*}{ Industry Classification } & \multicolumn{2}{|c|}{$2010 \& 2014$} \\
\hline & & $\mathbf{N}$ & $\%$ \\
\hline 1 & Agriculture, plantation, animal husbandry, fishery, forestry & 18 & 3.86 \\
\hline 2 & $\begin{array}{l}\text { Mining, coal mining, crude petroleum and natural gas production, metal and mineral } \\
\text { mining, and land/stone quarrying }\end{array}$ & 42 & 9.01 \\
\hline 3 & $\begin{array}{l}\text { Basic industry and chemicals, including cement, ceramics, glass, porcelain, metal and } \\
\text { allied products, chemicals, plastics and packaging, animal feed, wood industries, and } \\
\text { pulp and paper }\end{array}$ & 58 & 12.45 \\
\hline 4 & $\begin{array}{l}\text { Miscellaneous industries, including machinery and heavy equipment, automotive and } \\
\text { components, textile and garment, footwear, and cable }\end{array}$ & 48 & 10.30 \\
\hline 5 & $\begin{array}{l}\text { Consumer goods industries, including food and beverages, tobacco manufacturers, } \\
\text { pharmaceuticals, cosmetics, and housewares }\end{array}$ & 52 & 11.16 \\
\hline 6 & Property, real estate, and building constructions & 50 & 10.73 \\
\hline 7 & Infrastructure, utilities, and transportation, including energy, toll roads, airports & 46 & 9.87 \\
\hline 8 & Financial & 34 & 7.30 \\
\hline \multirow[t]{2}{*}{9} & $\begin{array}{l}\text { Trade, services, and investment, including wholesale, retail trade, restaurant, hotel, and } \\
\text { tourism }\end{array}$ & 118 & 25.32 \\
\hline & Total & 466 & 100.00 \\
\hline
\end{tabular}


(vi) property, real estate, and building constructions, (vii) infrastructure, utilities, and transportation, (viii) financial, (ix) trade, services, and investment. From Table 4, it can be concluded that companies involved in the trade, service and investment sectors are most likely to disclose their CSER activities in annual reports (25.32 percent), while the financial sector is least likely (7.30 percent).

\section{Results and Discussion}

\subsection{Descriptive Statistics}

Table 5 presents the descriptive statistics of variables. The result indicates that the average company including in this study is large in size. The mean (median) of their total assets is $771.56(2,176.94)$ million rupiahs. The firm size ranged widely from 23.18 to 236,027 billion rupiahs. The mean of ROA suggests that companies have a relatively low financial performance. With a minimum value ROA of $-80.82 \%$ and overall mean (median) is $6.02 \%(10.66 \%)$. The low ROA ratio may be a reflection of global economic conditions with companies around the world experiencing financial hardship during the global financial crisis.

\subsection{Univariate and Multivariate Analysis Results}

Table 6 presents the results of independent sample t-test. In hypothesis 1 , it is stated that the mean of CSER information disclosed in 2014 is higher than in 2010. This result can be seen of based on the independent sample t-test result; the mean of CSERD in 2014 is 21.60 percent, and statistically significant different from the year 2010 (13.39 percent). Thus, the first hypothesis is accepted.

Table 7 provides the results of regression analysis for Model I. Based on the table, it can be seen that government regulation positively affects the extent of CSERD. Thus, the second hypothesis is accepted. Regarding control variables, the result also show that industry type and firm size have a positive effect on the extent of CSERD.

Based on Table 8, it can be concluded that the market valued the CSERD information, which is provided by firms. The coefficient of CSERD is positive (2.197) and the p-value is .000 .

As for test results of independent sample t-tests presented in Table 6, there was an increase in the extent of CSERD in 2010 compared to in 2014. A significant increase in CSERD is likely caused by several factors. Firstly, companies have

Table 5: Descriptive Statistics Continuous Variables

\begin{tabular}{|l|c|c|c|c|c|c|}
\hline \multicolumn{1}{|c|}{ Variables } & $\mathbf{N}$ & Min & Max & Mean & Median & Std.Dev \\
\hline MVE & 466 & -14.78 & 383124.38 & 13301.78 & 2428.71 & 37198.58 \\
\hline CSERD & 466 & .06 & .079 & .18 & .14 & .09 \\
\hline FirmSize & 466 & 23.18 & $236,027.00$ & 771.56 & $2,176.94$ & $17,880.93$ \\
\hline Liability & 466 & 1.00 & $115,840.00$ & $5,343.43$ & $1,540.21$ & $11,820.66$ \\
\hline EBIT & 466 & -972.65 & $29,220.00$ & 800.40 & 134.26 & $2,485.37$ \\
\hline ROA & 466 & -80.82 & 85.05 & 6.02 & 4.58 & 10.57 \\
\hline Leverage & 466 & 1.01 & 43.21 & 2.57 & 2.07 & 2.64 \\
\hline
\end{tabular}

Table 6: The Result of Independent Sample t-test

\begin{tabular}{|c|c|c|c|c|c|c|c|}
\hline CSERD & \multirow[t]{2}{*}{$\mathbf{N}$} & \multirow{2}{*}{ Mean } & \multicolumn{2}{|c|}{$\begin{array}{c}\text { Levene's test for equality } \\
\text { variances }\end{array}$} & \multicolumn{2}{|c|}{ t-test for equality means } & \multirow[t]{2}{*}{$\begin{array}{c}\text { Mean } \\
\text { difference }\end{array}$} \\
\hline Year & & & $\mathbf{F}$ & Sig. & $\mathbf{t}$ & Sig. & \\
\hline $\begin{array}{l}2014 \\
2010\end{array}$ & $\begin{array}{l}233 \\
233\end{array}$ & $\begin{array}{l}.2160 \\
.1339\end{array}$ & $\begin{array}{l}- \\
-\end{array}$ & $\begin{array}{l}- \\
-\end{array}$ & - & $\begin{array}{l}- \\
-\end{array}$ & $\begin{array}{l}- \\
-\end{array}$ \\
\hline \multicolumn{3}{|c|}{ Equal variances assumed } & 51.77 & .000 & 10.55 & .000 & .0826 \\
\hline \multicolumn{3}{|c|}{ Equal variances not assumed } & & & 10.55 & .000 & .0826 \\
\hline
\end{tabular}


Table 7: Regression Results of Model I

\begin{tabular}{|l|c|c|c|c|c|c|}
\hline \multicolumn{1}{|c|}{ Variables } & $\begin{array}{c}\text { Prediction } \\
\text { sign }\end{array}$ & $\begin{array}{c}\text { Coefficient } \\
\text { regression }\end{array}$ & $\mathbf{t}$ & $\mathbf{p}$-value & \multicolumn{2}{c|}{ Multicollinearity } \\
\cline { 5 - 7 } & & -3.662 & -16.284 & .000 & - & Tolerance \\
\hline Constant & + & .098 & 1.827 & .043 & .796 & 1.257 \\
\hline GOVREG & + & .225 & 4.198 & .000 & .802 & 1.247 \\
\hline Industry type & +127 & 8.050 & .000 & .897 & 1.114 \\
\hline FirmSize & + & -.004 & -1.689 & .093 & .925 & 1.081 \\
\hline ROA & - & -.018 & -.317 & .751 & .895 & 1.118 \\
\hline Leverage & + & \multicolumn{5}{l}{} \\
\hline
\end{tabular}

Table 8: Regression Results of Model II

\begin{tabular}{|c|c|c|c|c|c|c|}
\hline \multirow{2}{*}{ Variables } & \multirow{2}{*}{$\begin{array}{l}\text { Prediction } \\
\text { sign }\end{array}$} & \multirow{2}{*}{$\begin{array}{l}\text { Coefficient } \\
\text { regression }\end{array}$} & \multirow{2}{*}{$\mathbf{t}$} & \multirow{2}{*}{ p-value } & \multicolumn{2}{|c|}{ Multicollinearity } \\
\hline & & & & & Tolerance & VIF \\
\hline Constant & & -4.277 & -8.394 & .000 & - & - \\
\hline CSERD & + & 2.197 & 3.132 & .000 & .789 & 1.268 \\
\hline Liability & - & .756 & 18.758 & .000 & .670 & 1.493 \\
\hline EBIT & + & 1.230 & 4.776 & .000 & .821 & 1.218 \\
\hline \multicolumn{7}{|c|}{ Adjusted $\mathrm{R}^{2}=.763 ; \mathrm{F}=249.480 ; \mathrm{p}$-value $=.000 ; \mathrm{N}=466$} \\
\hline $\begin{array}{l}\text { Dependent va } \\
\text { responsibility }\end{array}$ & $\begin{array}{l}\mathrm{MVE}=\mathrm{ma} \\
\text { sure; liabilit) }\end{array}$ & $\begin{array}{l}\text { ue of equi } \\
=\text { earnings }\end{array}$ & $\begin{array}{l}\text { enden } \\
\text { ncome }\end{array}$ & תCEPC & e social & ntal \\
\hline
\end{tabular}

been responding positively to regulations established by governments such as Government Regulation Number 47 (2012). Referring to the institutional theory, the presence of government regulations that require companies, especially those categorized as high profile, to disclose their CSR activities has delivered a positive effect on the level of CSR disclosure. Secondly, the increase in the CSERD level also demonstrates the increased corporate obedience to government regulation (normative isomorphism). In practice, regulatory pressures entice firms to report CSR activities through imposition and inducement mechanisms (DiMaggio \& Powell, 1983). Under the imposition mechanism, every firm must comply with standards and regulations unconditionally and under the inducement mechanism, by complying with regulations, firms have opportunities to gain several incentives such as access to resources and reputation.

This study examines the effect of government regulations on CSERD practices and confirms the hypothesis that regulation pressures positively and significantly affect CSERD practices. The results suggest that the role of government intervention has a positive effect in encouraging companies to engage in CSER activities and reporting. It is consistent with the institutional theory that posits that institutional pressures such as government regulation can boost and shape the behaviors of companies to disclose their involvement in CSER activities. Furthermore, according to the institutional theory, the company responds to government pressures generally motivated by factors of legitimacy or symbolic and efficiency or substantive (DiMaggio \& Powell, 1983; Faisal et al., 2019). In the context of legitimacy, the company exposing more CSER information is based on its commitment to demonstrate its adherence to the Government as one of the key stakeholders. On the other hand, the substantive motive is driven by the normative isomorphism that companies as an institution should be able to contribute to social and environmental empowerment such as education, poverty alleviation, empowerment of small- and medium-sized enterprises, healthcare services as well as various forms of CSR practices as set forth in the Company Law Number 40 (2007).

The positive relationship between CSERD and the increase in market value can be explained from various perspectives. First, the increased positive relationship between CSERD and market value can be attributed to the 
interests of investors, who consider the CSERD as a means of reliability. By presenting reliable information such as CSER, the company will be positively considered by investors and stakeholders. This positive response will certainly impact the company's reputation (Hahn \& Kühnen, 2013). Second, CSER disclosures increase transparency and visibility in corporate social and environmental factors. Investors can use CSER information to assess the company's risk to the surrounding environment. Thus, the higher the transparency of CSER information, the better the investment decisions ( $\mathrm{Li}$ et al., 2018). Third, CSER disclosure may be used by investor as an input into market analysis and valuation processes (Dhaliwal et al., 2014). Investors will assume that companies with higher level of CSERD certainly have better social and environmental performance as to have higher competitiveness and lower future liabilities compared to lower level of CSERD firms (Clarkson et al., 2013).

\section{Conclusions}

Based on the result of hypothesis testing on the influence of the government regulation variable on CSERD, it can be explained that the existence of government regulation can increase CSERD. This finding suggests that the various voluntary CSER initiatives are unlikely to succeed if there is no pressure from the government in the form of binding regulations. The company seeks to comply with government regulations to maintain its viability and to build a good image to the community. Institutional theory explains that the good relationship between a company and its environment is expected to support the adoption of established regulations. Essentially, CSER is a form of transformation of the natural law into a positive law, which suggests that ethical change and moral responsibility might be a form of law that can be imposed, and there are sanctions in its enforcement. If the company is not willing to conduct CSR disclosure, then sanctions will be imposed on the company that violates the relevant laws and regulations. A company that provides higher CSER disclosure may convey a positive signal to the investors that it has good corporate governance and is socially responsible. Thus, the image of the company will increase in the community. Indirectly, this disclosure will positively affect the firm value. This is because investors will become more interested in investing in a company that is socially responsible.

\section{References}

Aerts, W., \& Cormier, D. (2009). Media legitimacy and corporate environmental communication. Accounting, Organizations and Society, 34(1), 1-27. doi:10.1016/j.aos.2008.02.005

Al-Tuwaijri, S. A., Christensen, T. E., \& Hughes, K. E. (2004). The relations among environmental disclosure, environmental performance, and economic performance: A simultaneous equations approach. Accounting, Organizations and Society, 29(5-6), 447-471. doi:10.1016/s0361-3682(03)00032-1

Ali, W., Frynas, J. G., \& Mahmood, Z. (2017). Determinants of Corporate Social Responsibility (CSR) Disclosure in Developed and Developing Countries: A Literature Review. Corporate Social Responsibility and Environmental Management, 24(4), 273-294. doi:10.1002/csr.1410

Atan, R., Alam, M. M., Said, J., \& Zamri, M. (2018). The impacts of environmental, social, and governance factors on firm performance. Management of Environmental Quality: An International Journal, 29(2), 182-194. doi:10.1108/meq-032017-0033

Barakat, F. S. Q., Lopez Perez, M. V., \& Rodriguez Ariza, L. (2015). Corporate social responsibility disclosure (CSRD) determinants of listed companies in Palestine (PXE) and Jordan (ASE). Review of Managerial Science, 9(4), 681-702.

Buallay, A. (2019). Is sustainability reporting (ESG) associated with performance? Evidence from the European banking sector. Management of Environmental Quality: An International Journal, 30(1), 98-115. doi:10.1108/meq-12-2017-0149

Cahaya, F. R., Porter, S., Tower, G., \& Brown, A. (2015). The Indonesian Government's coercive pressure on labour disclosures. Sustainability Accounting, Management and Policy Journal, 6(4), 475-497. doi:10.1108/sampj-09-2014-0051

Cahaya, F. R., Porter, S. A., \& Brown, A. (2008). Social disclosure practices by Jakarta stock exchange listed entities. Journal of the Asia-Pacific Centre for Environmental Accountability, 14(1), 2-11.

Cahaya, F. R., Porter, S. A., Tower, G., \& Brown, A. (2012). Indonesia's low concern for labor issues. Social Responsibility Journal, 8(1), 114-132. doi:10.1108/17471111211196610

Campbell, D. J. (2000). Legitimacy theory or managerial reality construction? Corporate social disclosure in Marks and Spencer Plc corporate reports, 1969-1997. Accounting Forum, 24(1), 80-100.

Cho, C. H., Michelon, G., Patten, D. M., \& Roberts, R. W. (2015). CSR disclosure: the more things change...? Accounting, Auditing \& Accountability Journal, 28(1), 14-35. doi:10.1108/ aaaj-12-2013-1549

Clarkson, P. M., Fang, X., Li, Y., \& Richardson, G. (2013). The relevance of environmental disclosures: Are such disclosures incrementally informative? Journal of Accounting and Public Policy, 32(5), 410-431. doi:10.1016/j.jaccpubpol.2013.06.008

Coetzee, C. M., \& van Staden, C. J. (2011). Disclosure responses to mining accidents: South African evidence. Accounting Forum, 35(4), 232-246. doi:10.1016/j.accfor.2011.06.001

Cormier, D., \& Magnan, M. (2015). The Economic Relevance of Environmental Disclosure and its Impact on Corporate Legitimacy: An Empirical Investigation. Business Strategy and the Environment, 24(6), 431-450. doi:10.1002/bse.1829

De Klerk, M., de Villiers, C., \& van Staden, C. (2015). The influence of corporate social responsibility disclosure on share prices. 
Pacific Accounting Review, 27(2), 208-228. doi:10.1108/par05-2013-0047

Deegan, C. (2002). Introduction: The legitimising effect of social and environmental disclosures - a theoretical foundation. Accounting, Auditing \& Accountability Journal, 15(3), 282311. doi:10.1108/09513570210435852

Dhaliwal, D., Li, O. Z., Tsang, A., \& Yang, Y. G. (2014). Corporate social responsibility disclosure and the cost of equity capital: The roles of stakeholder orientation and financial transparency. Journal of Accounting and Public Policy, 33(4), 328-355. doi:10.1016/j.jaccpubpol.2014.04.006

Dienes, D., Sassen, R., \& Fischer, J. (2016). What are the drivers of sustainability reporting? A systematic review. Sustainability Accounting, Management and Policy Journal, 7(2), 154-189. doi:10.1108/sampj-08-2014-0050

DiMaggio, P. J., \& Powell, W. W. (1983). The Iron Cage Revisited: Institutional Isomorphism and Collective Rationality in Organizational Fields. American Sociological Review, 48(2), 147-160.

Djajadikerta, H. G., \& Trireksani, T. (2012). Corporate social and environmental disclosure by Indonesian listed companies on their corporate web sites. Journal of Applied Accounting Research, 13(1), 21-36. doi:10.1108/09675421211231899

Faisal, F., Napitupulu, M. A., \& Anis, C. (2019). Corporate Social and Environmental Responsibility Disclosure in Indonesian Companies: Symbolic or Substantive? Journal of Social Sciences \& Humanities, 27(1), 259-277.

Faisal, F., Tower, G., \& Rusmin, R. (2012). Legitimising Corporate Sustainability Reporting roughout the World. Australasian Accounting Business and Finance Journal, 6(2), 19-34.

Famiola, M., \& Adiwoso, S. A. (2016). Corporate social responsibility diffusion by multinational subsidiaries in Indonesia: organisational dynamic and institutional effect. Social Responsibility Journal, 12(1), 117-129. doi:10.1108/srj10-2013-0128

Fatemi, A., Glaum, M., \& Kaiser, S. (2017). ESG performance and firm value: The moderating role of disclosure. Global Finance Journal. doi:10.1016/j.gfj.2017.03.001

Frisko, D. (2012). Exploring potential power of corporate social responsibility toward sustainability development: analysis of state-owned company social responsibility in Indonesia. International Journal Sustainable Strategic Management 3(3), 205-220.

Garcia-Sanchez, I.-M., Cuadrado-Ballesteros, B., \& FriasAceituno, J.-V. (2016). Impact of the Institutional Macro Context on the Voluntary Disclosure of CSR Information. Long Range Planning, 49(1), 15-35. doi:10.1016/j.lrp.2015.02.004

Guidry, R. P., \& Patten, D. M. (2010). Market reactions to the firsttime issuance of corporate sustainability reports. Sustainability Accounting, Management and Policy Journal, 1(1), 33-50. doi:10.1108/20408021011059214
Gunawan, J. (2007). Corporate Social Disclosures by Indonesian Listed Companies: A Pilot Study. Social Responsibility Journal, 3(3), 26-34. doi:10.1108/17471110710835554

Gunawan, J. (2015). Corporate social disclosures in Indonesia: stakeholders' influence and motivation. Social Responsibility Journal, 11(3), 535-552. doi:10.1108/srj-04-2014-0048

Hahn, R., \& Kühnen, M. (2013). Determinants of sustainability reporting: a review of results, trends, theory, and opportunities in an expanding field of research. Journal of Cleaner Production, 59, 5-21. doi:10.1016/j.jclepro.2013.07.005

Haji, A. A. (2013). Corporate social responsibility disclosures over time: evidence from Malaysia. Managerial Auditing Journal, 28(7), 647-676. doi:10.1108/maj-07-2012-0729

Hidayati, N. D. (2011). Pattern of corporate social responsibility programs: a case study. Social Responsibility Journal, 7(1), 104-117. doi:10.1108/17471111111114576

Kuzey, C., \& Uyar, A. (2017). Determinants of sustainability reporting and its impact on firm value: Evidence from the emerging market of Turkey. Journal of Cleaner Production, 143, 27-39. doi:10.1016/j.jclepro.2016.12.153

Lee, K.-H., Cin, B. C., \& Lee, E. Y. (2016). Environmental Responsibility and Firm Performance: The Application of an Environmental, Social and Governance Model. Business Strategy and the Environment, 25(1), 40-53. doi:10.1002/ bse. 1855

Li, Y., Gong, M., Zhang, X.-Y., \& Koh, L. (2018). The impact of environmental, social, and governance disclosure on firm value: The role of CEO power. The British Accounting Review, 50(1), 60-75. doi:10.1016/j.bar.2017.09.007

Limkriangkrai, M., Koh, S., \& Durand, R. B. (2017). Environmental, Social, and Governance (ESG) Profiles, Stock Returns, and Financial Policy: Australian Evidence. International Review of Finance, 17(3), 461-471. doi:10.1111/irfi.12101

Ling, T. C., \& Sultana, N. (2015). Corporate social responsibility: what motivates management to disclose? Social Responsibility Journal, 11(3), 513-534. doi:10.1108/srj-09-2013-0107

Mahadeo, J. D., Oogarah-Hanuman, V., \& Soobaroyen, T. (2011). A Longitudinal Study of Corporate Social Disclosures in a Developing Economy. Journal of Business Ethics, 104(4), 545558. doi:10.1007/s10551-011-0929-3

Marquis, C., Glynn, M. A., \& Davis, G. F. (2007). Community Isomorphism and Corporate Social Action. Academy of Management Review, 32(3), 925-940.

Martínez-Ferrero, J., \& García-Sánchez, I.-M. (2017). Coercive, normative and mimetic isomorphism as determinants of the voluntary assurance of sustainability reports. International Business Review, 26(1), 102-118. doi:10.1016/j. ibusrev.2016.05.009

Mehedi, S., \& Jalaludin, D. (2020). Application of theories in CSR research focusing study context and corporate attributes. International Journal of Ethics and Systems. [Online First]. doi:10.1108/ijoes-09-2019-0146 
Meyer, J. W., \& Rowan, B. (1977). Institutionalized Organizations: Formal Structure as Myth and Ceremony. American Journal of Sociology, 83(2), 340-363.

Mirfazli, E. (2008). Corporate social responsibility (CSR) information disclosure by annual reports of public companies listed at Indonesia Stock Exchange (IDX). International Journal of Islamic and Middle Eastern Finance and Management, 1(4), 275-284. doi:10.1108/17538390810919592

Nguyen, S. L., Pham, C. D., Nguyen, A. H., \& Dinh, H. T. (2020). Impact of Corporate Social Responsibility Disclosures on Bankruptcy Risk of Vietnamese Firms. Journal of Asian Finance, Economics and Business, 7(5), 81-90. https://doi. org/10.13106/jafeb.2020.vol7.no5.081

Nguyen, T. L. H., Nguyen, T. T. H., Nguyen, T. T. H., Le, T. H. A., \& Nguyen, V. C. (2020). The Determinants of Environmental Information Disclosure in Vietnam Listed Companies. Journal of Asian Finance, Economics and Business, 7(2), 21-31. https:// doi.org/10.13106/jafeb.2020.vol7.no2.21

Nguyen, T. M. H., Nguyen, N. T., \& Nguyen, H. T., Nguyen. (2020). Factors Affecting Voluntary Information Disclosure on Annual Reports: Listed Companies in Ho Chi Minh City Stock Exchange. Journal of Asian Finance, Economics and Business, 7(3), 53-62. https://doi.org/10.13106/jafeb.2020.vol7.no3.53

Oeyono, J., Samy, M., \& Bampton, R. (2011). An examination of corporate social responsibility and financial performance. Journal of Global Responsibility, 2(1), 100-112. doi:10.1108/20412561111128555

Othman, S., Darus, F., \& Arshad, R. (2011). The influence of coercive isomorphism on corporate social responsibility reporting and reputation. Social Responsibility Journal, 7(1), 119-135. doi:10.1108/17471111111114585

Pedersen, E. R. G., Neergaard, P., Pedersen, J. T., \& Gwozdz, W. (2013). Conformance and Deviance: Company Responses to Institutional Pressures for Corporate Social Responsibility Reporting. Business Strategy and the Environment, 22(6), 357373. doi:10.1002/bse. 1743

Qiu, Y., Shaukat, A., \& Tharyan, R. (2016). Environmental and social disclosures: Link with corporate financial performance. The British Accounting Review, 48(1), 102-116. doi:10.1016/j. bar.2014.10.007
Rusmanto, T., \& Williams, C. (2015). Compliance Evaluation on CSR Activities Disclosure in Indonesian Publicly Listed Companies. Procedia - Social and Behavioral Sciences, 172, 150-156. doi:10.1016/j.sbspro.2015.01.348

Santoso, A. H., \& Feliana, Y. K. (2014). The Association Between Corporate Social Responsibility And Corporate Financial Performance. Issues in Social and Environmental Accounting, 8(2), 82-103.

Sarumpaet, S., Nelwan, M. L., \& Dewi, D. N. (2017). The value relevance of environmental performance: evidence from Indonesia. Social Responsibility Journal, 13(4), 817-827. doi:10.1108/10.1108/SRJ-01-2017-0003

Schadewitz, H., \& Niskala, M. (2010). Communication via responsibility reporting and its effect on firm value in Finland. Corporate Social Responsibility and Environmental Management, n/a-n/a. doi:10.1002/csr.234

Siregar, S. V., \& Bachtiar, Y. (2010). Corporate social reporting: empirical evidence from Indonesia Stock Exchange. InternationalJournal of Islamic and Middle Eastern Finance and Management, 3(3), 241-252. doi:10.1108/17538391011072435

Velte, P. (2017). Does ESG performance have an impact on financial performance? Evidence from Germany. Journal of Global Responsibility, 8(2), 169-178. doi:10.1108/jgr-11-2016-0029

Waagstein, P. R. (2010). The Mandatory Corporate Social Responsibility in Indonesia: Problems and Implications. Journal of Business Ethics, 98(3), 455-466. doi:10.1007/ s10551-010-0587-x

Wang, Z., \& Sarkis, J. (2017). Corporate social responsibility governance, outcomes, and financial performance. Journal of Cleaner Production, 162, 1607-1616. doi:10.1016/j. jclepro.2017.06.142

Xu, B., \& Zeng, T. (2016). Profitability, state ownership, tax reporting and corporate social responsibility: evidence from Chinese listed firms. Social Responsibility Journal, 12(1), 2331. doi:10.1108/srj-06-2014-0076

Zheng, L., Balsara, N., \& Huang, H. (2014). Regulatory pressure, blockholders and corporate social responsibility (CSR) disclosures in China. Social Responsibility Journal, 10(2), 226245. doi:10.1108/srj-08-2012-0102 